\title{
VILLAMOS KÖTÉSEK VIZSGÁLATA HŐKAMERÁVAL
}

\section{INVESTIGATION OF ELECTRIC CONNECTIONS USING THERMAL IMAGER}

\author{
Haraszti Ferenc \\ Óbudai Egyetem, Bánki Donát Gépész és Biztonságtechnikai Mérnöki Kar, Gépésze- \\ ti és Biztonságtudományi Intézet, Cím: 1081, Magyarország, Budapest Népszínház \\ utca 8; Telefon: +36-1-666-5434; haraszti.ferenc@,bgk.uni-obuda.hu
}

\begin{abstract}
A part of the electric connections has a corrosion aptitude. It can find a galvanic corrosion process danger in case of the contact between different electron potential metals. This process impairs the connection resistance and mechanical properties. The conduction parameters decrease in some under power parts because the heat increasing. This heat effect can be unperceived. By the way of thermal imager tests this irregularity can be discovered on time. In this work I want to present this investigation and the emerging problems.
\end{abstract}

Keywords: Galvanic corrosion, resistance, thermal imager

\section{Összefoglalás}

A villamos kötések egy része korróziós elváltozásra hajlamos. Különböző potenciálú fémek érintkezésekor galvánkorróziós folyamatok indulhatnak be. Ez károsan befolyásolja a kötés átmeneti ellenállását, mechanikai tulajdonságait. Az áramjárta részekben hő termelődik, rontva a villamos vezetés paramétereit. E hőhatások sokáig észrevehetetlenek. Hőkamera alkalmazásával a kötés rendellenességei időben detektálhatók. Cikkemben a mérés menetét, nehézségeit mutatom be.

Kulcsszavak: galvánkorrózió, ellenállás, hökamera

\section{Bevezetés}

A villamos- és energiaipar nélkülözhetetlen elemei, alkatrészei a villamos kötések. Ezek általában két -vagy többelemből álló kapcsolatok, melyek feladata az áramvezetés és a mechanikai szilárdság biztosítása. Ezen kötések anyagukat tekintve többfélék lehetnek. Legytöbbször rezet, acélt, alumíniumot, ezüstöt és ezeknek a különböző ötvözeteit használják fel. Gazdasági megfontolásokból adódóan többnyire két különböző fém kerül szoros kapcsolatba egymással. Ezek a környezet és az áramerősség ha- tására, de főként a fémek elektródpotenciáljának különbözősége miatt kontakt (galván) korróziós hatásnak vannak kitéve. A kialakuló korróziós reakciótermékek rontják az érintkezési mechanikát, így a megnövekedett átmeneti ellenállás hatására a kötések elkezdenek felmelegedni. Ezek vizsgálhatósága az elmúlt évekig körülményes és nehézkes volt. A hőmérséklet mérése üzem közben életveszélyes, a leállás pedig gazdasági károkat okoz. A közelmúltban a hőkamera ára jelentősen csökkent, így adva lehetőséget biztonságosabb mérésekhez, hiszen érintés nélkül is meghatározható a hőmér- 
séklet. E módszer azonban kellő rutint és hozzáértést igényel a valós eredmények megszerzéséhez.

\subsection{A termográfia alapjai}

Az infrasugárzáson alapuló hőmérsékletmérés, illetve a hőkamerás mérési módszer a testek hősugárzó képességétől függ. A hőmérsékleti sugárzás az a folyamat, amely az anyag hőmozgása miatt elektromágneses hullámokat bocsát ki magából. Ennek az energiának a nagy része másik testre átvetülve emittálódhat vagy reflektálódhat, továbbá transzmittálódhat is. Ha a vizsgált darabra érkező sugárzást az maradék nélkül elnyeli, akkor abszolút fekete testről beszélhetünk. Amennyiben teljes mértékben visszaverődik, akkor abszolút tükröződő teströl, és ha a testen teljes mértékben áthalad, akkor átlátszó anyagról beszélhetünk. A hősugárzásnak, mint elektromágneses hullám terjedésnek közvetítóközegre nincs szüksége. A hősugárzás alaptörvénye a Stefan-Boltzmann törvény:

$$
\mathrm{E}_{(\mathrm{f})}(\mathrm{T})=\sigma \times \mathrm{T}^{4},
$$

ahol:

$\mathrm{E}_{(\mathrm{f})}$ - fekete test emissziós képessége;

$\sigma$ - Stefan-Boltzmann féle állandó

$$
\text { 5,67 10-8 [J/m } \left.\mathrm{m}^{2} \mathrm{~K}^{4}\right] \text {; }
$$

$\mathrm{T}$ - hömérséklet $[\mathrm{K}]$.

A törvény szerint a $T$ hőmérsékletü fekete test egységnyi felülete által egységnyi idő alatt kisugárzott teljes energia arányos a test hőmérsékletének negyedik hatványával. Látható tehát, hogy idealizált esetben csak a fekete test képes az összes hőenergiát elnyelni és azt kisugározni. Ilyen a valóságban azonban nincs. A különböző anyagok más és más mértékben képesek az energiát emittálni. Minél inkább hasonlítanak az ideális fekete test tulajdonságaihoz annál pontosabb mérést tesznek lehetővé. Ellenkező esetben korrigálnunk kell a mérési eredményünket.

\subsection{Az infrasugárzás mérési elve és lehetőségei}

Mint az eddigiekből láthattuk, a bennünket körülvevő tárgyak láthatatlan elektromágneses sugarakat is bocsátanak ki magukból. Ahhoz, hogy ezeket érzékelni tudjuk, megfelelő berendezésre van szükségünk, amely érzékelők segítségével villamos jelekké alakítja át ezeket a sugarakat. A jeleket egy speciális elektronika digitalizálja. A digitalizált eredményt a szemünk által érzékelhető színekké transzformálja. Ez a berendezés a hőkamera vagy az infravörös hőmérő. Müködési elve az 1. ábrán látható.

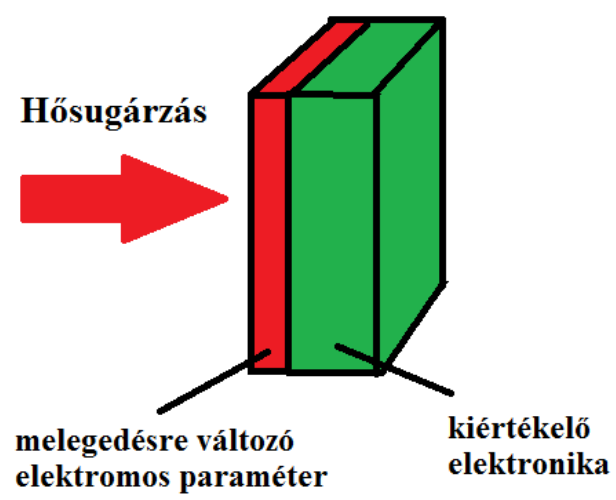

\section{1. ábra. Termikus detektorok müködése [5]}

Ahhoz, hogy a valóságnak megfelelö hömérsékleti értéket kapjunk, figyelembe kell vennünk az ideális fekete testtől való eltérést. Leegyszerüsítve elmondható, hogy a valós hőmérsékleti intenzitást a következő paraméterek befolyásolják:

$$
\varepsilon+\rho+\tau=1,
$$

ahol:
$\varepsilon$ - emissziós tényező;
$\rho$ - reflexiós tényező;
$\tau$ - transzmissziós tényező 
A gyakorlatban az emissziós tényező mindig kisebb, mint 1. A transzmissziós tényezőt a legtöbb anyagnál elhanyagolhatjuk, ebből következően csak az első két fizikai változóval kell számolnunk. Annál pontosabb a mérés minél jobban megközelítjük a test valódi hősugárzás-kibocsátási képességét $(\varepsilon)$. Ezt a korrekciót a modern kamerák specifikációi teszik lehetővé. Legkisebb változtatást a sötét érdes anyagoknál, legnagyobb eltérést pedig a világos, fényes felületeken kell deklarálnunk. Az érintés nélküli hőmérsékletmérés kivitelezhetetlen polírozott, tükörszerü, fénytanilag átlátszó felületeknél. Az 1. táblázat a villamos iparban használt néhány szerelési anyag sugárzás kibocsátó képességét mutatja.

1. táblázat. Sugárzás kibocsátó képesség

\begin{tabular}{|c|c|c|}
\hline Fém & Felület & $\boldsymbol{\varepsilon}$ \\
\hline vas & oxidált & $0,45-0,85$ \\
\hline alumínium & oxidált & $0,18-0,45$ \\
\hline sárgaréz & oxidált & $0,45-0,5$ \\
\hline
\end{tabular}

\section{Termokamera használata a gya- korlatban}

Az eddigiekből kiderült, hogy a pontos felületi hőmérséklet értékét nagyban befolyásolja a mérendő tárgy emissziós tényezője és annak a helyes korrekciója. Nagyságrendi hibát vétünk ennek a rossz megítélésével (100-150\%). Eddigi tapasztalataim szerint más paramétereket is figyelembe kell venni. Mindig eltérést mutat a közvetlen érintéssel és a kamerás (infrahőmérős) méréssel meghatározott eredmény. A pontatlanság következhet az infrasugár valamilyen közegen való áthaladásából vagy a helytelenül megválasztott mérési hullámhossz (rövid vagy hosszú) alkalmazásából. A villamos kötések üzem közbeni legmagasabb hőmérséklete tapasztalataim szerint a $300^{\circ} \mathrm{C}$. A legpontosabb mérési eredményt hosszú hullámú elven müködő hőkamerával kaptam. Gondot okoz a mérendő felületen található nagyszámú anyagminőség előfor- dulása, a nem megfelelő felbontású termokamera (pixelenkénti állítható lehetőséggel) hibás eredményeket detektál. Problémát okozott kültéri méréseknél a napszak helyes megválasztása is, mert ügyelni kell a napsugárzás okozta interferenciák elkerülésére. Mérőszekrényben, üzem alatt lévő kapcsolótáblákon érdemes több helyröl és legalább ötször elvégezni az ellenőrző méréseket. Kritikus, nagy pontosságot igénylő, biztonságot befolyásoló méréseknél érdemes hibaszámítást végezni a megfelelő hibahatár megállapításához. Gyakorlati tapasztalat, hogy a mérendő tárgy színe a mérési eredményre csak nagyon kis mértékben gyakorol hatást $(0,1-0,3 \%)$.

\section{3. Összefoglalás}

Cikkemben kísérletet tettem egy, az iparban új hőmérséklet mérési módszer bemutatására a teljesség igénye nélkül. Az érintés nélküli termokamerás vizsgálat lehetővé teszi a hibásan, nem rendeltetésszerüen működő villamos kötések, más elektromos és mechanikus berendezések vizsgálatát. A módszer előnye a gyorsasága, balesetveszély-mentes használata és a működés közbeni analizálási lehetősége. Ez utóbbi gazdasági megtakarításokat is eredményez. A hőkamerák nagy tömegben történő gyártása lehetővé teszi a könnyebb elérhetőségüket. Az elektronika mai fejlettségi szintje egyre kisebb és könnyebb berendezések gyártását eredményezi, megkönnyítve az alkalmazhatóságukat és a mobilizálhatóságukat. Cikkemben igyekeztem bemutatni a termokamerás mérés legfontosabb fizikai hátterét, s mint gyakorlati felhasználó, öszszefoglaltam a azokat az empirikus összefüggéseket melyekkel minél precízebben elvégezhető a mérés, a megvalósítás szempontjából.

\section{Köszönetnyilvánítás}

A kísérletekben való közreműködésért szeretnék köszönetet mondani Dr. Kovács 
Tünde egyetemi docensnek és Pásztor László okleveles villamosmérnöknek (Robert Bosch Kft.).

\section{Szakirodalmi hivatkozások}

[1] Kocsisová E.; Dománková M.: Másodlagos fázisok kiválásának vizsgálata AISI 316 ausztenites korrózióálló acélban. EME kiadó, Kolozsvár, 2013, 189-192.

[2] Kovács-Coskun T.; Völgyi B.; Sikari-Nágl I.: Kontaktkorróziós jelenség tanulmányozása acél alumínium párositásánál. EME kiadó, Kolozsvár, 2013, 201-204.

[3] Réti T, Kovács T: A Phenomenological Method for the Prediction of Damage Accumulation Processes under Varying External Conditions. Materials Science Forum, Vol. 414-415, 2003, 317-322.

[4] Dr. Kovács Klára: Korróziós alapfogalmak. Müszaki Könyvkiadó, Budapest, 1965.

[5] http://www.pim-kft.hu (2017.02.15.)

[6] www.villanylap.hu (2017.02.22.) 